\title{
TANTANGAN PENDIDIKAN SUMBER DAYA MANUSIA YANG PROGRESIF DAN DEMOKRATIS
}

\author{
${ }^{1}$ Bahartiar \\ Universitas Muhammadiyah Kendari \\ Bahartiarvirgo69@gmail.com \\ ${ }^{2}$ SahrulSyawal \\ Universitas Indonesia Timur \\ ahroel_s@yahoo.com
}

\begin{abstract}
Abstrak
Pendidikan progresif yang demokratis menghendaki suatu perencanaan pendidikan dan kurikulum atas prinsip-prinsip yang dinamis dan demokratis, bukan pola-polastatis. Apa yang mereka butuhkan dalam kurikulum ialah mendorong perkembangan pribadi yang meliputi perkembangan minat, berfikir dan kemampuan praktis. Dalam hal ini filsafat progresivisme ingin membentuk keluaran (output) yang dihasilkan dari pendidikan sekolah yang memiliki keahlian dan kecakapan (skill) yang langsung dapat diterapkan di masyarakat luas. Pendidikan progresivisme yang demokratis menghendaki bentuk yang bervariasi dan isi kurikulum yang kaya nilai moral, serta pemerataan dalam pendidikan.
\end{abstract}

Kata-kata kunci: progresif, pendidikan sumber daya manusia, demokratis

\section{A. Pendahuluan}

Perkembangan ilmu pengetahuan dan teknologi yang terjadi hingga saat ini, telah membawa perubahan di hampir semua aspek kehidupan manusia dimana berbagai permasalahan hanya dapat dipecahkan kecuali dengan upaya penguasaan dan peningkatan ilmu pengetahuan dan teknologi. Selain manfaat bagi kehidupan manusia di satu sisi perubahan tersebut juga telah membawa manusia ke dalam era persaingan global yang semakin ketat. Gempuran teknologi dan informasi digital inilah yang menjadi salah satu permaslahan serius dalam dunia Pendidikan saatini (Helaluddin, 2018). Agar mampu berperan dalam persaingan global, maka sebagai bangsa kita perlu terus mengembangkan dan meningkatkan kualitas sumber daya manusianya.

Uno dan Lamatenggo (2016: 227) berpendapat bahwa betapapun bangsa kita mengalami krisis moneter, krisis moral, ketidakstabilan politik, bangsa Indonesia tengah mengalami restrukturisasi global dunia yang sedang berjalan, yang ditandai dengan berbagai perubahan dalam semua aspek kehidupan, baik di negara maju apalagi di negara yang sedang berkembang seperti Indonesia. Oleh karena itu, peningkatan kualitas sumber daya manusia merupakan program pendidikan yang 
nyata dan yang segera harusd ilakukan secara demokratis berkeadilan, terencana, terarah, intensif, efektif dan efisiendalam proses pembangunan, kalau tidak ingin bangsa Indonesia kalah bersaing dengan bangsa lain dalam menjalani era globalisasi ini, yang bukan saja merupakan abad baru melainkan pula abad beradaban baru.

Kalau kita cermati, negara-negara maju yang ada saat ini pasti memiliki system pendidikan yang bagus dan berkualitas tinggi. Lihat saja Amerika, Cina, Jepang, Korea Selatan, Jerman, Perancis, Finlandia, dan lainnya. Pendidikan menjadi pilar utama untuk menopang sebuah peradaban suatu bangsa. Karena sekaya apapun negerinya, seluas apapun wilayahnya, dan sebanyak apapun penduduknya namun kalau tidak dikelola dengan baik dan benar maka potensi tersebut malah akan menjadibeban. Dan pendidikan menjadi peran yang signifikan dalam mengelola potensi-potensi yang ada tersebut. Menurut Malik Fajar (Rusniati, 2015: 106) bahwa era globalisasi yang penuh dengan tantangan merupakan masa yang tidak terhindarkan.Untuk itu lembaga pendidikan, harus mampu menjawab tantangan tersebut dengan merubaharah dan orientasi pendidikan secara demokratis dan berkeadilan universal.

\section{B. Gambaran Kualitas Pendidikan Sumber daya Manusia Indonesia}

Pendidikan yang mengutamakan sumberdaya manusia yang bermutu, tentu saja akan melahirkan hasil yang baik. Artinya, jika sumberdaya manusia diasah dengan berbagai kompetensi kecerdasan multiple yang lebih unggul tetapi tetap sesuai ideologis moralitas bangsa, maka hasilnya akan memuaskan bahkan membanggakan. Namun upaya untuk membentuk sumberdaya manusia menjadi pribadi yang berkarakter handal dan kompetitif dan sesuai ideologis moralitas bangsa tidaklah mudah, tentunya membutuhkan proses yang sangat panjang dan memerlukan kesabaran. Dalam hal ini, upaya-upaya dalam memupuk sumber daya manusia Indonesia, hanya dapat di lakukan jika pengupayaanya melalui proses pendidikan (proses studi) dan manajemenisasi yang dilakukan secara sadar pula, terpadu dan bersinergis (masyarakat-keluarga-pemerintah), terencana, sistimatik, dan secara terus berkesinambungan diupayakan peningkatan pengembangannya.

Gambaran tentang seberapa baik Indonesia mengembangkan sumber daya manusianya, ditampilkan pada table hasil laporan World Economic Forum (WEF):

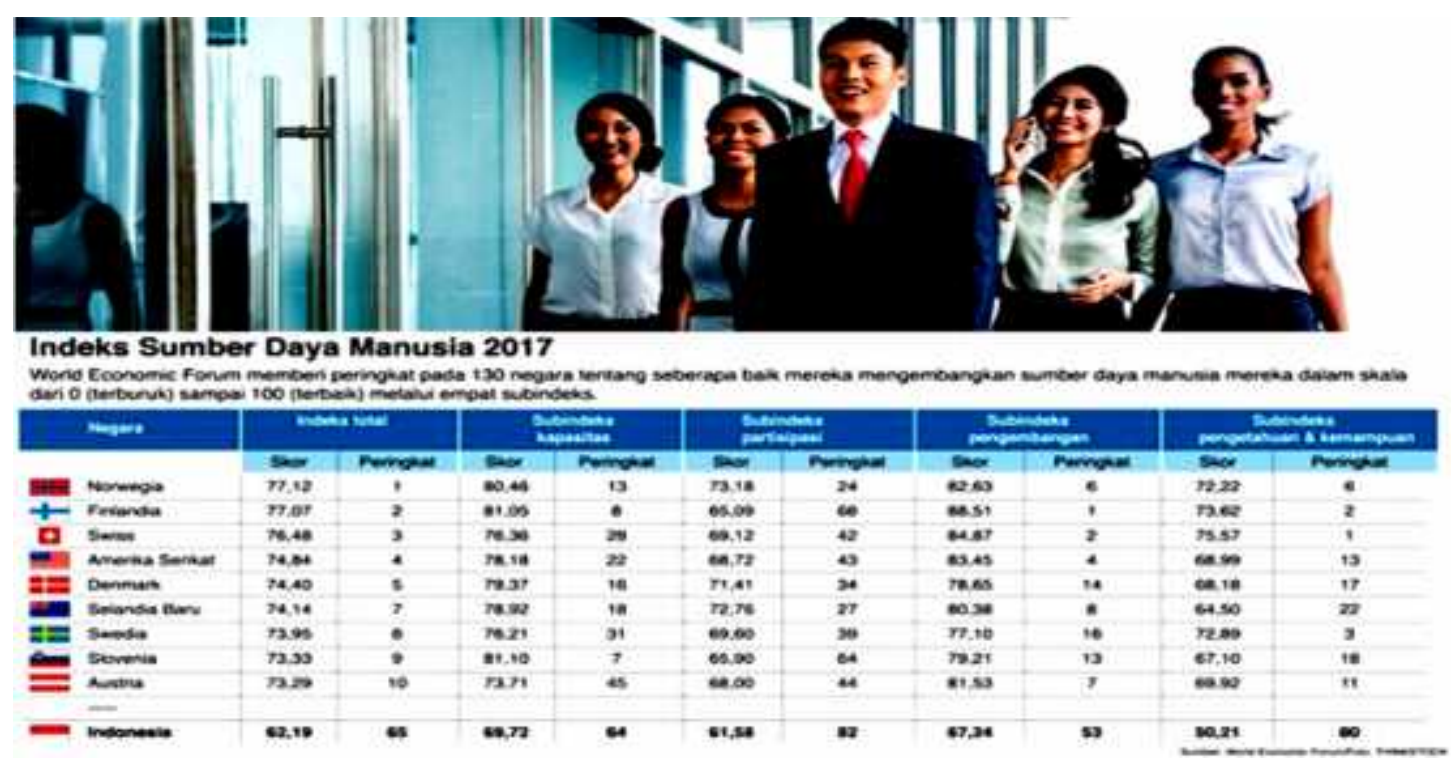


Sumber Media Indonesia: darihttp://www.mediaindonesia.com/news/read/122587/kualitassdm-indonesia-meningkat/2017-09-15, di akses sabtu, 28 Oktober 2017 12:49.

Mencermati tulisan hasil laporan World Economic Forum (WEF) yang dirilis Rabu (13/9) seperti ditampilkan pada table sebelumnya, memperlihatkan realitas hasil bahwa kualitas sumber daya manusia (SDM) Indonesia belumlah mencapai pengembangan yang baik seperti yang diharapkan. Dalam laporan berjudul Global Human Capital Report 2017 itu, yang mengkaji kualitas SDM pada 130 negara berdasarkan sejumlah indikator yang dipakai, Indonesia berada di urutan ke-65 dengan nilai indeks total 62,19. Data statistic itu tidak berbeda pula dengan data Laporan Pembangunan Manusia 2016, yang dipublikasikan Program Pembangunan PBB (UNDP), bahwa indeks IPM (IPM ialah alat pengukur kualitas manusia) pembangunan manusia Indonesia dengan indicator pendidikan, kesehatan, dan kemiskinan, pada tahun 2015 berada di urutan 113 dari 188 negara dengan Nilai indeks IPM sebesar 0,689 dan masuk dalam kelompok negara dengan pembangunan manusia menengah (dalam situs; http://www.mediaindonesia.com/editorial/read/1190/ $\underline{\mathrm{html} / 2017-10-14)}$

Harus jujur diakui bahwa Indonesia masih tertatih-tatih dalam pembangunan di bidang pendidikan sumber daya manusianya, di samping bidang kesehatan, dan jaminan sosial. Sumber daya manusia yang unggul dan berkualitas merupakan asset utama bagi pembangunan bangsa. Meskipun ketersediaan sumber daya alam (natural resources) yang melimpah dan didukung pula dengan sumberdaya modal serta teknologi yang semakin canggih, tidakakan berkontribusi yang bernilai tambah, tanpa didukung adanya sumber daya manusia (human resources) yang berkualitas. Sumber daya manusia yang berkualitas akan dapat dicapai melalui pendidikan yang berkualitas pula.

Pendidikan yang berkualitas akan berkorelasi positif dengan sumber daya manusia yang berkualitas pula. Perihal itu, dibuktikan antara lain berdasarkan data dalam Education For All (EFA) Global Monitoring Report (2011): The Hidden Crisis, Armed Conflict and Education yang dikeluarkan Organisasi UNESCO-PBB yang diluncurkan di New York (1/3/2011), indeks pembangunan pendidikan atau education development index (EDI) berdasarkan data tahun 2008 adalah 0,934. Nilai itu menempatkan Indonesia di posisi ke-69 dari 127 negara di dunia. Total nilai EDI itu diperoleh dari rangkuman perolehan 4 kategori penilaian, yaitu: angka partisipasi pendidikan dasar, angka melek huruf pada usia 15 tahun ke atas, angka partisipasi menurut kesetaraan jender, angka bertahan siswa hingga kelas V tingkat Sekolah Dasar (SD). Meskipun demikian posisi Indonesia saat ini masih jauh lebih baik dari Filipina (85), Kamboja (102), India (107), dan Laos (109). Menurut Education For All (EFA) bahwa kualitas pembangunan pendidikan berkorelasi dengan kualitas pengembangan sumber daya manusia, maka dapat dikatakan bahwa indeks kualitas pembangunan pendidikan nasional di Indonesia untuk pengembangan sumber daya manusianya, masih berada pada level pengembangan yang berkatagori cukup rendah 
(darihttp://disdikpora.palangkaraya.go.id/berita-160-kualitas-pendidikan-indonesiaranking-69-tingkat-dunia.html, diunduh 16 Oktober 2017).

Pendidikan berkontribusi signifikan dalam meningkatkan kualitas hidup suatu bangsa, tentu pula bagi bangsa Indonesia. Namun sayangnya kualitas pembangunan pendidikan kita masihlah belum mampumenjawab permasalahan terkaitkualitas pendidikan sumber daya manusianya. Data-data tentang rendahnya kualitas pendidikan Indonesia itu, maknanya jelas ada something wrong (masalah) dalam system pendidikan Indonesia. Ditinjau secara perspektif ideologis (prinsip) dan perspektifteknis (praksis), berbagai masalah itu dapat dikategorikan dalam 2 (dua) masalah yaitu: Pertama; masalah mendasar, yaitu kekeliruan paradigm pendidikan yang mendasari keseluruhan penyelenggaran system pendidikan; dan Kedua, masalahmasalah cabang, yaitu berbagai problem yang berkaitan aspek praktis/teknis yang berkaitan dengan penyelenggaraan pendidikan, seperti mahalnya biaya pendidikan, rendahnya prestasi siswa, rendahnya sarana fisik, rendahnya kesejahteraaan guru, dan sebagainya. Muhammad Idrus, (2012) mengemuakan pula bahwa jika hendak dianalisis, masalah-masalah terkait dengan kajian pendidikan, setidaknya ada 4 hal yang menjadi focus kajiannya: yaitu (1) pemerataan pendidikan, (2) mutu pendidikan, (3) relevansi pendidikan, dan (4) efisiensi pengelolaan pendidikan. Keempat titik focus permasalahan pendidikan tersebut, pada akhirnya juga menjadi sebuah kebijakan untuk menangani pendidikan, sehingga pada akhirnya banyak upaya yang dilakukan oleh pemerintah untuk mengatasi keempat persoalan tersebut.

Dewasa ini kita dapat bercermin pada realitas kehidupan masyarakat bangsa Indonesia, maka tidak mungkin masyarakat Indonesia mampu masuk atau berproses dalam era globalisasi pada masa ini. Untuk itulah, pada sekarang ini ada dua garis besar masalah pokok setelah di atas dijabarkan beberapa poin masalahnya yaitu; bagaimana seluruh komponen masyarakat dapat berproses secara terpadu ke ruang pendidikan, dan yang kedua yaitu bagaimana pendidikan yang dilalui dapat membekali peserta didik dalam terjun kekehidupan kekinian dengan tidak melepaskan hakikat pendidikan yang sesungguhnya disertai pula dengan wawasan nilai moral kebangsaan yang Berketuhanan Yang MahaEsa. Penyesuaian objek sasaran program pendidikan terhadap perkembangan zaman dan tuntutan akan kebutuhan masyarakat global, penting untuk segera dioreantasi kembali. Denganbegitu, diharapkan pembangunan pendidikan nasional ke depan mampu mencetak masyarakat sebagai sumber daya manusia pendidikan yang tangguh, bermoral dan berintelektual pada ranah persaingan global bebas saat ini. Tilaar (2004; dalam Kurniawan, 2012: 4) mengemukakan bahwa Progresivisme menjadi relevan untuk diadopsi, mengingat pentingnya kesiapan sekolah memasuki era Masyarakat Ekonomi ASEAN (MEA) dan era global.Oleh karenaitu, sepantasnyalah untuk disadari bahwa pentingnya upaya demokratisasi dalam system pendidikan Indonesia yang lebih progresif. 


\section{Deskripsi Singkat tentang Ideologi Filsafat Pendidikan Progresivisme}

Kata kunci untuk memahami filsafat pendidikan progresivisme adalah dengan melihat kata sifat yang terkandungdalamterminologitersebut, yakni kata "progresif". Kemajuan (progress) bersifat alamiah (naturalistic) yang mengimplikasikan perubahan. Perubahan mengimplikasikan kebaruan. Kebaruan tersebut terdapat di dalam realitas. Pendidikan yang progressif selalu menekankan cara memecahkan masalah terhadap realitas yang selalu mengalami perubahan atau dengan kata lain pendidikan yang progresif selalu mencoba mengembangkan inisiatif dan kepercayaan diri seseorang. Brubhacer (1978: dalamFitri Al Faris, 2015) mengatakan:Progress is naturalistic: it implies change. Change implies noveltyand novelty lays claim to being genuine rather than the revalationof an antecedently complete reality".

Progresivis memerupakan aliran filsafat yang lahir di Amerika Serikat sekitar abad ke-20. John S. Brubacher, mengatakan bahwa filsafat progressivisme bermuara pada aliran filsafat pragmatisme yang diperkenalkan oleh William James (1842-1910), dimana Isu utama pragmatism adalah terletak pada pandangannya yang mementingkan kegunaan praktis, dan mendasarkan filsafatnya pada pengalaman empirik, oleh William James menyebutnya sebagai pengalaman empiris meradikal (dalam Jalaluddin dan Abdullah Idi, 2012: 70). Menurut Milton K. Munitz (dalam Idris, Saifullah. 2014: 35), bahwa kata pragmatic, secara umum mencakup pengertian praktis dan realistik, mencoba secara bebas demokratis berbagai ide dalam sebuah proyek untuk dilihat sejauh mana ia dapat diterapkan dalam praktek untuk tujuan tertentu, terbuka dan fleksibel, tidak terlalu serius atau fanatik dalam berpegang pada dogma tertentu, menilai suatu gagasan atau keyakinan dengan menggunakan ukuran sejauh mana ia mencapai kesuksesan.

Tampaknya filsafat progresivisme menuntut kepada para penganutnya untuk selalu maju (progres) dengan bertindak secara konstruktif, inovatif, reformatif, aktif dan dinamis. Sebab naluri manusia selalu menginginkan perubahan-perubahan. Manusia tidak mau hanya menerima satu macam keadaan saja, tetapi juga inginhidupnyatidaksamadengan masa sebelumnya. Dan untukmendapatkanperubahanperubahan yang diinginkan tersebut, manusia harus memiliki pandangan hidup yang bertumpu pada sifat-sifatfleksibel (tidakkaku, tidak menola kperubahan, dan tidak terikat doktrin-doktrin tertentu), memiliki sifat toleran, curious (ingin mengetahui dan menyelidiki), dan open-minded (punya pikiran terbuka) (Jalaluddin dan Idi, 2012: 88). Perubahan-perubahan yang diinginkan tersebut, tentunya menyangkut pula hal perubahan-perubahan yang diinginkan dalam dunia pendidikan dalam perspektif yang progressive.

Menyimak uraian di atas, maka dapat dikatakan bahwa dalam dunia pendidikan, progresivisme sebagai aliran pendidikan ditopang oleh filsafat pragmatis sosial John Dewey, yang menghendaki implementasi sosial dalam dunia pendidikan yang dilakukan secara bebas dengan nilai demokratis dan berkeadilan. Henderson (1959) mengemukakan bahwa pendidikan progresivis medilandasi oleh paham filsafat naturalis meromantika dari Rousseau, dan pragmatism dari John Dewey. Dasar dari 
Rousseau yang melandasi progresivisme adalah pandangan tentang hakikat manusia yang bebas sesuai kodratnya, sedangkan dari pragmatisme Dewey adalah pandangan tentang minat dan kebebasan dalam teori pengetahuan (dalam Nanuru., Ricardo F, 2013: 134).

Pendidikan Progresivisme adalah sebuah teori dengan sistem pendidikan yang mementingkan kemerdekaan dan kebebasan anak dari tekanan pengajaran dengan system hafalan, pendiktean bahan pelajaran dan otorisasi terhadap buku teks. Para pendidik Progresivis memeyakini bahwa para murid belajar lebih baik apabila mereka dengan sungguh-sungguh sangat perhatian atas apa yang dipelajari, yaitu materi pelajaran yang disukai dan sebaliknya akan terjadi bahwa mereka tidak akan belajar dengan baik apabila mereka ditekan untuk menghafal dan mengingat berbagai macam fakta-fakta yang dianggap percuma. Anak-anak seharusnya belajar melalui kontak langsung dengan sesuatu objek pelajaran, tempat dan orang-orang sebagaimana dibaca atau didengarkan oleh mereka. "Child-centerred progressives saw the school as a place where children would be free to experiment, to play and to express themselves" (Ornstein dan Levine, 1985: dalamNanuru., Ricardo F, 2013: 135).

Filsafat progresivisme menekankan pada peningkatan kemampuan pesertadidik melalui pengalaman, kemampuan diri/kemandirian, dan selalu memperoleh perubahan-perubahan secara pribadi yang dapat menimbulkan apresiasi dan kreasi peserta didik, khsususnya dalam pengembangan potensi pesertadidik melalui pendidikan yang demokratis. Pengembangan dimaksud adalah bahwa peserta didik dapat memperoleh pengetahuan secara bebas mandiri dan terus memprogreskannya menjadi keunggulan baginya guna mencapai tujuan pendidikan. Aliran filsafat progresivisme menempatkan manusia sebagai mahkluk biologis yang utuh dan menghormati harkat dan martabat manusia sebagai pelaku hidup yang demokratis. Beberapa pandangan (dalam Vega Ricky Salu dan Triyanto, 2017: 31) mengemukakan bahwa aliran filsafat progresivisme telah memberikan sumbangan yang besar dalam dunia pendidikan dewasa ini, dengan meletakan dasar-dasar kemerdekaan dan kebebasan yang demokratis kepada peserta didik, baik secara fisik, moral, maupun dalam ranah berpikir intelektual. Oleh karena itu filsafat progresivisme tidak menyetujui system pendidikan yang otoriter yang jauh dari nilai demokrasi. Sebab pendidikan yang otoriter akan mematikan tunas-tunas para pelajar untuk hidup sebagai pribadi-pribadi yang gembira menghadapi pelajaran dan mematikan daya kreasi baik secara fisik maupun psikis peserta didik.

\section{Paradigma Pendidikan Progressive yang Demokratis}

Frietz R Tambunan dalam (Susilo, 2007: 224-225) menjelaskan bahwa kata pendidikan berasal dari kata Latin educare yang secara harfiah berarti“menarik keluar dari" sehingga pendidikan adalah sebuah aksi membawa peserta didik keluar dari kondisi tidak merdeka, tidak dewasa, dan tergantung, kesuatu situasi merdeka, dewasa, dapat menentukan diri sendiri, dan bertanggungjawab. Pendidikan yang demokratis tidak saja bertujuan menciptakan manusia siap kerja, tetapi membentuk 
pula manusia matang dan berwatak yang siap belajar terus, siap menciptakan lapangan kerja (job creator), dan siap mengadakan transformasi sosial karena sudah lebih dahulu mengalami transformasi diri melalui pendidikan yang demokratis. Makap endidikan yang demokratis adalah sebuah proses pedagogis di mana seorang peserta didik dibebaskan dari ketidak matangan dan kebodohan menjadi seorang manusia matang, intelek, dan kultural.

Demokrasi diyakini sebagai sistem yang paling realistis dan rasional untuk mencegah suatu struktur masyarakat yang dominatif, refresif dan otoritarian dunia yang berkembang dewasa ini berevolusi kearah sistem yang lebih demokratis, tak terkecuali aspek kependidikan. Demokrasi merupakan suatu sistem yang bias menjamin keteraturan publik dan sekaligus mendorong transformasi masyarakat menuju suatu struktur sosial, politik, ekonomi dan kebudayaan (pendidikan) yang lebih ideal. Ideal dalam arti, manusiawi, egaliter dan berkeadilan (Masdar, 1999; dalam Siswanto, 2006: 245).

Demokrasi dalam pandangan ini kiranya telah menjelma sebagai tongkat mukjizat yang diharapkan mampu menempatkan masing-masing unsur yang saling berbeda dan beragam proporsinya di dalamlapisanmasyarakat yang majemuk tuntutan demokrasi tidak hanya terarah pada struktursosial, politik dan ekonomi, tetapi telah memasuki berbagai aspek kehidupan manusia, termasuk pendidikan. Karena itu,seluruh aspek kehidupan manusia yang berhubungan dengan masyarakat luas dan berada dalam system kenegaraan membutuhkan demokrasi, karena manusia sebagai hamba Tuhan butuh dimanusiakan dan dimanusiawikan (hakikat pendidikan), sedangkan demokrasi adalah ungkapan lain dari penghormatan hak-hak asasi manusia, suatu sikap hidup insani yang mencerminkan dimiliki dan ditegakkannya peradaban dan kebudayaan dalam suatu dinamika kehidupan (Syamsul Arifin dan Ahmad Barizi, 2001: 89).

Menurut Tilaar bahwa kehidupan demokrasi adalah kehidupan yang menghargai potensi individu, yaitu individu yang berbeda dan individu yang mau hidup bersama. Dengan demikian, segala jenis homogenisasi masyarakat yaitu menyamaratakan anggota masyarakat menuju uniformitas adalah bertentangan dengan prinsip hidup demokrasi. Termasuk di dalamnya pengakuan terhadap hak asasi manusia merupakan inti dari kehidupan demokrasi di dalam segala aspek kehidupan. Khususnya dalam pendidikan dalam perspektif Tilaar maka proses pendidikan harus mengembangkan kebebasan intelektual, kesempatan untuk bersaing, mengembangkan kepatuhan spiritual dan moral, pendidikan yang mengakui hak untuk berbeda dan percaya kepada kemampuan manusia (Tilaar, H.A.R., 2001: 11). Hal ini dapat dimaklumi karena pendidikan adalah unsur vital dalam setiap masyarakat, terutama masyarakat yang demokratis. Oleh karena itu dalam masyarakat yang demokratis, diharapkan system pendidikannya harus demokratis pula.

Menyiapkan pendidikan masyarakat yang demokratis adalah juga merupakan topik hangat yang menarik dibicarakan oleh para filosof aliran progresif. Dalam hal ini, Dewey merekomendasikan bahwa para pelajar ditawarkan kesempatan- 
kesempatan yang sesuai dengan umurnya untuk membuat pilihan di sekolah mereka, yaitu untuk melatih mempersiapkan sebuah hak yang mendasar dalam masyarakat yangliberal. Beberapa pengikut Dewey, menambahkan bahwa sekolah harus menyediakan ketrampilan-ketrampilan dan ilmu pengetahuan secara akademik, waktu dewasa akan membuktikan manfaatnya dalam kehidupan yang demokratis. Dalam mencari alternative untuk membentuk masyarakat yang demokratis maka diperlukan suatu kearifan dalam berfikir. Artinya, ketika mengadopsi suatu pandangan, aliran pemikiran atau trend suatu masyarakat tertentu, maka perlu memperhatikan dan mempertimbangkan aspek positif dan negatifnya. Sehingga rumusan alternative tersebut tidak bias dan berguna bagi pengembangan masyarakat, khususnya masyarakat Indonesia, yang semakin hari semakin ditantang oleh gencarnya arus globalisasi diseluruh penjuru dan aspek kehidupan. Oleh karena itu, demokratisasi pendidikanlah yang menjadi ujung tombak dalam mengahadapi semua ini (Idris, Saifullah. 2014: 70-71).

Demokrasi pendidikan adalah adanya persamaan kesempatan dalam pendidikan harus disediakan, dan tidak ada diskriminasi dalam masyarakat demokrasi (The Encyclopedia Americana dalam Idris, Saifullah. 2014: 14). Pemerataan pendidikan merupakan pula makna demokratisasi pendidikan yang harus dilakukan yang mencakup dua aspek penting yaitu equality dan equity. Equality atau persamaan mengandung arti persamaan kesempatan untuk memperoleh pendidikan, sedangkan equity bermakna keadilan dalam memperoleh kesempatan pendidikan yang sama diantara berbagai kelompok dalam masyarakat. Akses terhadap pendidikan yang merataberartisemua penduduk usia sekolah telah memperoleh kesempatan pendidikan, sementara itu akses terhadap pendidikan telah adil jika antar kelompok bisa menikmati pendidikan secara sama (Eka, R., 2007; dalam Mujahidun, 2016: 43).

Demokrasi secara literal menurut Christopher Winch dan John Gingell, Key yang mengutip pandangan Dewey (dalam Idris, Saifullah. 2014: 14) adalah "rule by the people", yang bermakna bahwa kehidupan modern berarti demokrasi. Demokrasi artinya membebaskan intelegensi secara efektif dan independen, untuk membebaskan pikiran sebagai sebuah organisme yang bersifat individu yang gunanya untuk melakukan pekerjaannya sendiri. Demokrasi dalam pendidikan membawa respek yang banyak pada individu sebagai individu, yang mempunyai kesempatan yang banyak untuk kebebasan dan berdemokrasi, punya inisiatif dalam bertindak dan berfikir, tidak membebankan diri sendiri dan melahirkan tanggungjawab-tanggungjawab (Idris, Saifullah. 2014: 14).

Demokrasi sebagai ungkapan lain dari penghormatan hak-hak asasi manusia, telah diterjemahkan dalam dunia pendidikan, yaitu dengan menciptakan kebebasan intelektual antara pendidik dengan peserta didik dalam proses belajar mengajar. Filsafat progresivisme yang diklaim sebagai the liberal road of the culture-pun mengajarkan agar akal dan kecerdasan peserta didik harus dikembangkan dengan baik, dengan menciptakan suasana yang dialogis, harmonis dan demokratis. Karena sekolah bukan hanya berfungsi sebagai transfer of knowledge (pemindahan 
pengetahuan) akan tetapi juga berfungsi sebagai transfer of value (pemindahan nilai), sehingga peserta didik menjadi terampil dan berintelektual baik secara fisik maupun psikis. Kurikulum yang diinginkan bersifat dinamis, fleksibel dan eksperimental (Siswanto, 2006: 244-260).

Hakikat pendidikan yang demokratis, dalam perspektif progressive adalah suatu pemerdekaan atau pembebasan. Tujuan pendidikan dalam suatu negara yang demokratis adalah membebaskan generasi anak bangsa dari hal kebodohan, kemiskinan dan berbagai "perbudakan" lainnya. Bagi negara, pendidikan adalah salah satu tugas yang terpenting, karena pendidikan merupakan kebutuhan pokok manusia yang istimewa. Pendidikan merupakan hak pribadi manusia yang berakar dalam aneka kebutuhan pokok manusia sebab manusia tidak bias mengembangkan hidupnya tanpa pendidikan minimum dan bermutu. Tanpa pendidikan, manusia akan tetap kerdil, tergilas kekuatan dan kekuasaan alam, terpenjara pesonamagis-misteri, dan seperti kata Asimov, tingkat kesadarannya hanya sebatas ide curiousity (instink) binatang dan takkan berubah menjadi creative curiousity, ciri orang terdidik. Dengan demikian, hak pendidikan bukan saja sekedar kebutuhan pokok fisik, tetapi juga kebutuhan pokok yang khasmanusiawi yang akhirnya didasarkan atas martabat manusia yang tidak bias ditawar (Siswanto, 2006: 251).

Progresivisme merupakan aliran filsafat pendidikan modern yang menghendaki adanya perubahan pelaksanaan pendidikan menjadi lebih maju. Aliran progresivisme ini mengutamakan penyelenggaraan pendidikan di sekolah agar lebih berpusat pada anak dan menjadikan pendidikhanya sebatas sebagai fasilitaor, pembimbing, dan pengarah bagi peserta didik. Adapun tujuan dari aliran progresivis medalam pendidikan ialah ingin merubah praktik pendidikan yang selama ini terkesan otiriter menjadi demokratis dan lebih menghargai potensi dan kemampuan anak, serta mendorong untuk dilaksanakannya pembelajaran yang lebih banyak melibatkan peserta didik. Dengan menerapkan aliran progresivisme dalam pendidikan, harapannya dapat membahwa perubahan dan kemajuan pendidikan di Indonesia menjadi lebih berkualitas, sehingga mampu mewujudkan tujuan pendidikan nasional Indonesia (Fadlillah, 2017: 17).

\section{E. PENUTUP}

Demokrasi pendidikan merupakan pendidikan hati nurani, artinya pendidikan yang lebih menghargai potensi manusia yang dikatakan lebih humanis dan beradab. Sebagaimana dikemukakan Tilaar (dalam Azzuhri, 2009: 151) bahwa demokrasi pendidikan dalam pengertian yang lebih luas, patut selalu dianalisis dan dirumuskan sebagai proses humanisasi. Humanisasi pendidikan akan menumbuhkan pemberdayaan manusia dan masyarakat melalui ilmu pengetahuan dan menempatkan kesadaran sebagai hasrat (intention) terhadap dunia, yang pada gilirannya akan mendinamisasikan perkembangan ilmu pengetahuan. Sehingga pendidikan bukanhanya sekadar menghidupi peserta didik tetapi mengembangkannya sebagai manusia (human being). Pendidikan bukanlah bertujuan untuk melahirkan robot-robot 
yang hanya menerima petunjuk dan arahan, akant etapi pendidikan yang progressive yang mengembangkan pribadi-pribadi yang kreatif, bermoral-intelektual, kritis dan produktif.

Upaya mencapai demokrasi pendidikan yang berwawasan humanis, Friere (1984) menyarankan adalah dengan menciptakan kebebasan intelektual antara pendidik dengan peserta didik dalam proses belajar mengajar. Proses tersebut harus terbuka, penuh dialog dan bertanggungjawab antara pendidik dan peserta didik dan interaksi antara mereka dalam bentuk egaliter dan kesetaraan (equity). Dengan adanya kesetaraan (eguity), kebebasan berinisiatif, berbeda aspirasi dan pendapat serta keadilan dalam pendidikan akan terakomodasi dengan baik, sebab pendidikan memangmerupakan sarana terpenting untuk mencapai kemerdekaan. 25 Dalam kontek sini, desain demokrasi pendidikan harus terjadi kesegala arah dan bukan hanya bersifat satu arah, yaitu dari pendidik ke peserta (top down) melainkan juga ada keseimbangannya, yaitudaripesertadidik dengan pendidik (buttom up) dan antarpesertadidik (network) (Siswanto, 2006: 251).

Sehubungan dengan pendidikan yang progressive, filsafat progresivisme telah memberikan sumbangan yang besar di dunia pendidikan dengan meletakkan dasardasar kemerdekaan dan kebebasan kepada anak didik, baik secara fisik maupun cara berfikir, guna mengembangkan bakat dan kemampuan yang terpendam dalam dirinya. Sebagai salah upaya menuju demokrasi pendidikan. Melalui demokrasi pendidikan akan terjadi proses kesetaraan antara pendidik dan peserta didik dalam proses pembelajaran. Dengan demikian, dalam proses pendidikan, perlu dikembangkan suatu komunikasi struktural dan cultural antara pendidik dan peserta didik, sehingga aka nterjadi interaksi yang sehat, wajar dan bertanggung jawab.

Oleh karenaitu, pendidikan yang juga sebagai bagian integral dalam proses pembangunan bangsa dalam rangka memperoleh suatu kemajuan yang progressive, maka pembangunan pendidikan hendaknya dibangun atas paradigma pendidikan progresif yang demokratis yang disertai pilar-pilar yang kokoh, diantaranya (Azzuhri, 2009: 154):

Pertama, pendidikan untuk semua warga masyarakat. Pendidikan harus berlangsung dari masyarakat, oleh masyarakat, dan untuk semua masyarakat. Pendidikan oleh masyarakat artinya masyarakat bukan merupakan objek pendidikan dari negara atau sekelompok penguasa, tetapi partisipasi aktif dari masyarakat, di mana masyarakat mempunyai peranan di dalam setiap langkah program pendidikannya. Pendidikan bersama-sama masyarakat artinya masyarakat diikutsertakan di dalam program-program pemerintah yang telah mendapatkan persetujuan masyarakat karena lahir dari kebutuhan nyata dari masyarakat itu sendiri.

Kedua, pendidikan demokratis yakni proses pendidikan yang mampu mengembangkan seluruh potensi peserta didik. Pendidikan demokratis merupakan model pendidikan yang mengembangkan prinsip-prinsip demokratis yakni pendidikan yang menghargai perbedaan pendapat (the right to be different), kebebasan untuk mengaktualisasikan diri, kebebasan intelektual, kesempatan untuk bersaing di dalam 
perwujudan diri-sendiri (self realization), pendidikan yang membangun moral dan yang semakin mendekatkan diri kepada Sang Penciptanya.

Ketiga, pendidikan yang bertumpu pada kebudayaan lokal. Bangsa Indonesia saat ini terancam disintegrasi bangsa. Hal ini sebagai akibat dari system pendidikan yang bersifat sentralistik yang telah lama diterapkan. Pendidikan sentralistik kurang mengakomodasi adanya kebudayaan kebhinekaan bangsa Indonesia dari Sabang sampai Merauke. Bangsa Indonesia yang terdiri dari berbagai pulau, kebiasaan, adat istiadat, agama, dan kebudayaan merupakan khazanah dalam mengembangkan sistem pendidikan.

Keempat, pendidikan yang seimbang antara imtaq dan iptek. Pendidikan harus dikonsepsikan sebagai aktualisasi sifat-sifat Allah pada manusia dan disusun sebagai suatu proses sepanjang hayat dan harus meliputi pengalaman pengalaman yang berguna dari berbagai sumber baik itu pengetahuan, keterampilan atau sikap, di dalam dan di luar sekolah yang akan menjadikan peserta didik dapat memikul tugas dan tanggungjawabnya kepada Allah, dirinya sendiri, sesame manusia dan lingkungannya.

Kelima, untuk mewujudkan pendidikan yang berkualitas perlu dilakukan tekad dari stakeholder pendidikan itu sendiri yang terdiri dari unsure structural meliputi unsure pemerintahan, Ditjen Dikti, Badan Akreditasi Nasional, Dewan Pendidikan Tinggi, Guru/Dosen, Pengelola Pendidikan, dan Masyarakat serta unsure cultural meliputi kurikulum pendidikan, Strategi Pengajaran, budaya lokal yang selaras dengan asas kebersamaan, berkesinambungan dan memanusiakan manusia dalam proses pengajaran, tidak memakai sistem top down tetapi memakai sistem buttom up. Dengan demikian, system pendidikan nasional akan memiliki pengetahuan umum dan iman yang mantap melalui strategi mobilitas sosial yang dapat menjawab tantangan perubahan di era global.

Selain itu pula, Pemerataan pendidikan yang menjadi hak dan kewajiban bagi setiap warga negara harus disikapi dan ditindaklanjuti secara demokratis dan berkeadilan oleh pemerintah melalui kebijakan perundang-undanganyang mengatur sedemikian rupahal berbagai potensi yang dapat menunjang agar warga negara memperoleh kesempatan pendidikan yang merata. Oleh karena itu, dalam rangka demokratisasi pendidikan yang progressive, dari, oleh, dan untuk masyarakat, maka pemerintah harus: 1) mengupayakan perluasan dan pemerataan kesempatan pendidikan yang bermutu tinggi bagi seluruh rakyat Indonesia menuju terciptanya manusia Indonesia berkualitas tinggi dengan peningkatan anggaran pendidikan secara berarti, 2) memberdayakan lembaga pendidikan baik sekolah maupun luar sekolah sebagai pusat pembudayaan nilai, sikap, dan kemampuan, serta meningkatkan partisipasi keluarga dan masyarakat yang didukung oleh sarana dan prasarana memadai, 3) melakukan pembaharuan dan pemantapan system pendidikan nasional berdasarkan prinsip desentralisasi, otonomi keilmuan dan manajemen yang progresif, 4) mengembangkan kualitas sumber daya manusia sedini mungkin secara terarah, terpadu dan menyeluruh melalui berbagai upaya proaktif dan reaktif oleh seluruh komponen bangsa agar generasi muda dapat berkembang secara optimal disertai 
dengan hak dukungan dan lindungan sesuai denganp otensinya, 5) memberikan subsidi pendidikan bagi sekolah swasta agar sekolah-sekolah swasta mampu menyelenggarakan pendidikan yang berkualitas dan memberikan layanan pendidikan yang dapat dijangkau masyarakat luas, 6) menerapkan alternative layanan pendidikan, khususnya bagi masyarakat kurang beruntung (masyarakat miskin, berpindah-pindah, terisolasi, terasing, minoritas, dan di daerah bermasalah, termasuk anak jalanan), seperti SD dan MI kecil satu guru, guru kunjung/sistem tutorial, SD Pamong, SD-MI terpadu, kelas jauh, serta SLTP-MTs terbuka; dan 7) memberikan beasiswa bagi siswa berprestasi dan/atau dari keluarga yang tidak mampu, dengan mempertimbangkan peserta didik perempuan secara proporsional.

Agar dapat mewujudkan pendidikan yang berkualitas perlu ada paradigm baru pendidikan yang progressive, sebagaimana dikemukakan oleh Waras Kamdi (dalam Susilo, 2007:227-229), yaitu: Pertama, perubahan visi kurikulum, dari visi kurikulum efisiensi social ke kurikulum yang fleksibel dan egaliter, atau dari kurikulum yang berwatak industrial-kapitalistik ke demokratis. Kurikulum efisiensi sosial yang berakar pada tradisi pendidikan kita dikembangkan atas dasar kebutuhan spesifik masyarakat (ekonomik-industrial); Kedua, perubahan pada ranah pembelajaran. Praktik pembelajaran yang kini didominasi teori belajar asosiasi dan behavioristik perlu digeser keteori belajar kognitif dan konstruktivistik. Pembelajaranakan berfokus pada pengembangan kemampuan intelektual yang berlangsung secara sosial dan kultural, mendorong siswa membangun pemahaman dan pengetahuannya sendiri dalam konteks sosial, dan belajar dimulai dari pengetahuan awal dan perspektif budaya. Tugas belajar didesain menantang dan menarik untuk mencapai derajat berpikir tingkat tinggi, dalam hal ini proses dipandang sama penting dengan hasil belajar, dan berpikir cerdas dikonsepsikan mencakup "metakognisi" atau kemampuan memonitor belajar dan berpikir sendiri. Pembelajaran bukan hanya mengandung informasi tetapi juga proses membangun watak dan identitas personal yang progresif. Dalam hal ini, termasuk pemberdayaan kualitas pendidikan yang dibedakan menjadi (1) pemberdayaan manusianya yaitu siswa, dan (2) pemberdayaan proses pendidikannya, meliputi peningkatan peranan guru professional dan pembelajarannya. Pemberdayaan siswa pada dasarnya dapat dilakukan dengan cara mengoptimalisasikan penampilan siswa sesuai dengan karakteristik perilaku anak pada usianya dan aktivitas pembelajarannya dengan menghindarkan mereka dari kebiasaan tergantung dan kebiasaan disuap, akan tetapi lebih diarahkan kepada kebiasaan mandiri, berinisiatif, produktif, berencana, tuntas, kreatif, sabar, jujur, terbuka atau transparan, dengan transaksi horizontal secara proporsional (Djohar MS, 2003: 179); dan Ketiga, perubahan strategi dan fungsi penilaian. Pengukuran yang eksak dan berstandar presisi dengan teknik tes (objektif) terstandar dan isomorfis serta perannya sebagai alat untuk "menghakimi" siswa mengakar kuat pada tradisi pendidikan kita kini. Penilaian terintegrasi dengan pembelajaran untuk mendukung proses belajar, dan siswa aktif mengevaluasi belajarnya sendiri. 
Kilpatrick mengatakan bahwa suatu kurikulum dianggap baik jika didasarkan pada tiga prinsip, yaitu: pertama, meningkatkan kualitas hidup anak didik pada tiap jenjang. Kedua, menjadikan kehidupan actual anak kearah perkembangan dalam suatu kehidupan yang bulat dan menyeluruh. Ketiga, mengembangkan aspek kreatif kehidupan sebagai suatu uji coba atas keberhasilan sekolah sehingga peserta didik dapat berkembang dalam kemampuannya yang actual untuk aktif memikirkan hal-hal baru yang baik untuk diamalkan, dan dalam hal ini apa saja yang ingin berbuat serta kecakapan efektif untuk mengamalkan secara bijaksana melalui pertimbangan yang matang. Berdasarkan pendapat Kilpatrick tersebut maka ada beberapa hal yang perlu diperhatikan dalam penyusunan kurikulum pendidikan, yaitu: pertama, kurikulum harus dapat meningkatkan kualitas hidup peserta didik sesuai dengan jenjang pendidikan. Kedua, kurikulum yang dapat membina dan mengembangkan potensi peserta didik. Ketiga, kurikulum yang sanggup mengubah perilaku anak menjadi kreatif, adaptif dan kemandirian. Keempat, kurikulum bersifat fleksibel atau luwes berisi tentang berbagai macam bidang studi. Inilah yang dimaksud Kilpatrick dengan istilah "emerging curriculum", yang dalam pelaksanaannya memakai metode proyek dengan berlandaskan belajar sambil berbuat melalui praktek kerja di laboratorim, di bengkel, di kebun, yang merupakan kegiatan belajar yang dianjurkan dalam rangka terlaksananya learning by doing dan pemecahan masalah (problem solving) (Siswanto, 2006: 258)

\section{F. DAFTAR PUSTAKA}

Azzuhri, Muhandis. 2009. Pendidikan Berkualitas; Upaya menuju Perwujudan Civil Society. Jurnal FORUM TARBIYAH Vol. 7, No. 2, Desember 2009 (p. 143-156) Sekolah Tinggi Agama Islam (STAIN) Pekalongan.

Djohar, MS. 2003. Pendidikan Strategik: Alternatifuntuk Pendidikan Masa Depan, Yogyakarta: Penerbit LESFI.

Fadlillah, M. 2017. Aliran Progresivisme dalam Pendidikan di Indonesia: Jurnal Dimensi Pendidikan dan Pembelajaran Vol. 5 No. 1 Januari 2017 (p 17-24) Universitas Muhammadiyah Ponorogo.

Fitri Al Faris. 2015. Kurikulum 2013 dalam Perspektif Filsafat Pendidikan Progressivisme. Jurnal Filsafat, Vol. 25, No. 2, Agustus 2015 (p.316-337). Universitas Gadjah Mada.

Helaluddin. 2018. Restrukturisasi Pendidikan Berbasis Budaya: Penerapan Teori Esensialisme di Indonesia. Jurnal Dimensi Pendidikan dan Pembelajaran Universitas Muhammadiyah Ponorogo, Vol. 6 No. 2, hlm. 74-82.

http://www.mediaindonesia.com/editorial/read/1190/html//2017-10-14.

http://disdikpora.palangkaraya.go.id/berita-kualitas-pendidikan-indonesia-ranking-69tingkat-dunia//html. diunduh 16 Oktober 2017. 
http://www.mediaindonesia.com/editorial/read/1190/saatnya-fokus-membangun-sdm/ 2017-10-14/htm. Diunduhtanggal 10-01-2018.

Idris, Saifullah. 2014. Demokrasi dan Filsafat Pendidikan (Filosofis dan Implikasinya dalam Pengembangan Filsafat Pendidikan). Banda Aceh: Ar-Raniry Press.

Jalaluddin dan Idi, A. 2012. "F ilsafat Pendidikan" Manusia, Filsafat dan Pendidikan", Yogyakarta: Ar-Ruzz Media.

Kurniawan, Syamsul. 2016. Sekolah Progresif. Jurnal Pendidikan AT-TURATS. Vol. 10 No. 1 (2016) (p.3 - 12).

Media Indonesia: darihttp://www.mediaindonesia.com/news/read/122587/kualitas-sdmindonesia-meningkat/2017-09-15, diakses sabtu, 28 Oktober 2017 12:49.

Muhammad Idrus. 2012. Mutu Pendidikan Dan Pemerataan Pendidikan Di Daerah (Quality of Education and Regional Educational Equity). Jurnal Psikopedagogia, Vol. 1, No. 2, Desember 2012 Issn: 2301-6167.

Mujahidun, 2016. Pemerataan Pendidikan AnakBangsa: Pendidikan Gratis Versus Kapitalisme Pendidikan; Jurnal Tarbiyatuna, Vol. 7 No. 1 Juni 2016. (p.38-53).

Nanuru, Ricardo F. 2003. Progresivisme Pendidikan dan Relevansinya di Indonesia. Jurnal UNIERA Volume 2 Nomor 2; Agustus 2003. (p.132-143). Universitas Halmahera.

Rusniati, 2015. Pendidikan Nasional dan Tantangan Globalisasi: Kajian kritister hadap pemikiran A. Malik Fajar. Jurnal Ilmiah Didaktika Vol. 16, No. 1, Agustus 2015 | p.102-128), Program Pascasarjana UIN Ar-Raniry Banda Aceh.

Siswanto. 2006. Filsafat Progressivis medan Demokrasi Pendidikan (Menggagas Pembelajaran Demokratis. Jurnal Tadrîs. Volume 1. Nomor 2. 2006 (p.244-260.

Susilo, M. Joko. 2007. Pembodohan Siswa Tersistematis. Yogyakarta: Pinus Book Publisher.

Syamsul, Arifin dan Ahmad Barizi. 2001. Paradigma Pendidikan BerbasisPluralisme dan Demokrasi, Rekonstruksi dan Aktualisasi Tradisi Ikhtilaf dalam Islam. Malang: UMM Press.

Tilaar, H.A.R., 2001. Paradigma Baru Pendidikan Nasional. Jakarta: Rineka Cipta.

Uno dan Nina Lamatenggo. 2016. Landasan Pendidikan. Jakarta: Bumi Aksara

Vega Ricky Salu dan Triyanto. 2017. Filsafat Pendidikan Progresivisme dan Implikasinya dalam Pendidikan Seni di Indonesia. Jurnal Imajinasi Vol XI. Nomor 1, Bulan Januari 2017, (p. 29-42). Universitas Negeri Semarang. 